\title{
The sociology of individuality and the history of urban society
}

\author{
Moritz Föllmer ${ }^{\star \dagger}$ \\ Department of History, University of Amsterdam, Postbus 1610, 1000 BP Amsterdam, The Netherlands \\ ${ }^{\star}$ Corresponding author. Email: m.foellmer@uva.nl
}

(First published online 12 September 2019)

\begin{abstract}
This article explores the role of individuality in Europe's urban past. In so doing, it builds on Georg Simmel's famous article 'The metropolis and mental life' as well as recent work especially by Bernard Lahire, Niklas Luhmann and Uwe Schimank. The article brings out key sociological insights and links them to a range of studies by urban historians, which are thus revisited from a fresh angle. The focus is on three key dimensions of the modern city: first, sites of social and cultural life; secondly, politics and government; thirdly, nonhumans such as material objects, animals and natural elements.
\end{abstract}

At the beginning of the twentieth century, Georg Simmel proposed an analysis of how individuality and the urban condition are intertwined in modern times. In his famous article 'Die Großstädte und das Geistesleben', he argued that the big city enabled an unprecedented degree of personal freedom by providing an anonymous environment that freed individuals from social control. ${ }^{1}$ This anonymity, however, had a downside: it reduced individuals' influence and visibility. In the big city, driven by a clockwork-like rationality and impersonal relations, they did not count for much. Individuals protected themselves from the daily onslaught of urban life by becoming indifferent to sensory impressions and developing a reserved attitude towards others. At the same time, they longed to be valued. Hence, their inclination to seek solace in intellectual fashions, such as an extreme individualism inspired by Friedrich Nietzsche which, as Simmel astutely pointed out, was staunchly anti-urban yet popular chiefly in the big city.

\footnotetext{
${ }^{\dagger}$ A first version of these reflections was presented at a workshop of the Urban Agency network in Antwerp. I would like to thank Bert de Munck for this opportunity and the participants for their questions. Further thanks are due to Rüdiger Graf and the anonymous reviewer for their critical readings.

${ }^{1}$ G. Simmel, 'Die Großstädte und das Geistesleben' (1903), in G. Simmel, Aufsätze und Abhandlungen 1901-1908, ed. R. Kramme, A. Rammstedt and O. Ramstedt (Frankfurt, 1995), 116-31; for a translation into English, see 'The metropolis and mental life', in K.H. Wolff, ed., The Sociology of Georg Simmel (New York, 1950), 409-24. Geistesleben, however, can be translated both as 'intellectual life' and as 'mental life'.

(C) The Author(s) 2019. This is an Open Access article, distributed under the terms of the Creative Commons Attribution licence (http://creativecommons.org/licenses/by/4.0/), which permits unrestricted re-use, distribution, and reproduction in any medium, provided the original work is properly cited.
} 
As early as 1846, the socialist writer Ernst Dronke, a sometime friend of Karl Marx, had written that the anonymity of Berlin created a space for both solitude and pleasure. Extramarital affairs or even cohabitation could be enjoyed among other tempting activities, undermining the family as a consequence. ${ }^{2}$ Simmel's originality thus lay less in his observations as such than in his shift from moral critique to sociological argument. For the sake of this argument, he focused on a particular side of 'the metropolis', inspired by his native Berlin, with which he had an ambivalent relationship. ${ }^{3}$ In other writings, he recognized that urban individuals do not remain isolated from each other but connect and socialize with like-minded individuals. ${ }^{4}$ In 'Die Großstädte und das Geistesleben', however, he foregrounded large, anonymous spaces such as the Potsdamer Platz, through which thousands of commuters moved hastily and impatiently - not the residential neighbourhoods that offered less impersonal environments, the industrial areas with their factories and working-class populations or the government district with its politicians, bureaucrats and military officers. But one need not overgeneralize the picture provided in 'Die Großstädte und das Geistesleben' to acknowledge its importance in highlighting the crucial relationship between individuality and urban society.

To what extent has this citation classic been used as a starting point for further research and thought? It did, of course, inspire another citation classic, namely Louis Wirth's 'Urbanism as a way of life. ${ }^{5}$ But in recent years, urban sociologists and urban theorists have produced a rich secondary literature on Simmel without, it seems to me, making much actual effort to follow in the intellectual footsteps of his article. ${ }^{6}$ Their focus continues to be on collectives: class, ethnic or political identities, however much the fluidity of these identities is then stressed. The reluctance to engage with individuality might also have to do with political reservations. 'The individual', certainly since the emergence of neoliberalism, has been hailed by American Republicans and British Tories, with whom humanities scholars and social scientists are overwhelmingly at loggerheads. Witness, for instance, the prominent urban theorist David Harvey's unequivocally negative picture of a mere 'aura of freedom of choice' in contemporary cities, of 'intense possessive individualism' complemented by 'individualistic isolation, anxiety and neurosis.' ${ }^{7}$ But acknowledging the importance of individuality does not necessitate acceptance of the neoliberal

\footnotetext{
${ }^{2}$ E. Dronke, Berlin (Darmstadt, 1974), 16-17, 29, 34.

${ }^{3}$ For contextualizations, see D. Frisby, 'Social space, the city and the metropolis', in D. Frisby, Simmel and Since: Essays on Georg Simmel's Social Theory (London, 1992), 98-117; D. Jazbinsek, 'The metropolis and the mental life of Georg Simmel', Journal of Urban History, 30 (2003), 102-25.

${ }^{4}$ This is pointed out by D. Frisby, Cityscapes of Modernity: Critical Explorations (Cambridge, 2001), 156-7; W.-D. Bukow, 'Was heißt hier ethnische Gemeinschaftsbildung? Zur nachhaltigen Marginalisierung gemeinschaftsorientierter Bindungen', in H.A. Mieg, A.O. Sundsboe and M. Bieniok (eds.), Georg Simmel und die aktuelle Stadtforschung (Wiesbaden, 2011), 213-42, at 228-30.

${ }^{5}$ First published in American Journal of Sociology, 44 (1938), 1-24.

${ }^{6}$ The illuminating but largely programmatic contributions in Mieg, Sundsboe and Bieniok (eds.), Georg Simmel, vindicate this assessment. Important historical studies that have recently worked with Simmel's reflections on, respectively, exhibitions and hotels are A.C.T. Geppert, Fleeting Cities: Imperial Expositions in Fin-de-Siècle Europe (Basingstoke, 2010), and H. Knoch, Grandhotels: Luxusräume und Gesellschaftswandel in New York, London und Berlin um 1900 (Göttingen, 2016).

${ }^{7}$ D. Harvey, Rebel Cities: From the Right to the City to the Urban Revolution (London, 2012), 14. There is a parallel here to the frequent stereotyping of suburban life in urban studies; see the critical remarks by
} 
attempt to redefine and monopolize it. In their pertinent critique of 'identity' as a concept for cultural analysis, Rogers Brubaker and Frederick Cooper propose several alternative categories, including 'self-understanding. ${ }^{8}$ If Brubaker and Cooper's suggestion is plausible, then there should be no theoretical barrier to acknowledging that some self-understandings are individualist and taking an analytical interest in these.

Two examples can serve to illustrate this difference between a pejorative view and an analytical interest. The concluding chapter of a collection on Leeds in the 1990s and 2000s comprises a section entitled 'Postmodern Leeds: from collectivism to individualism'. The authors approvingly cite voices that deplore the transition from the working-class communities of the industrial age to a city dominated by the service economy and higher education. Uninclined to take any scholarly distance, they blame the decline of 'collectivism' on 'the legislations of Thatcher and post-Thatcher administrations' and the promotional discourse of Leeds' councillors and planners. The authors do not appear to be truly interested in the transition to 'individualism' and the broader cultural changes that underpinned it. ${ }^{9}$ By contrast, a recent study by Benjamin Holtzman of how the principle of owneroccupied housing spread in 1970s New York against much initial resistance is too nuanced to attribute the shift 'solely to a powerful real estate industry or the unabashedly pro-gentrification policies of leaders such as [Mayor Ed] Koch'. Instead, it recognizes 'the emerging acceptance of conversions and ownership by tenants' and the 'grassroots support from those who benefited economically', thus acknowledging the role of individualist self-understandings and practices. ${ }^{10}$

Holtzman is by no means the only urban historian who has taken an interest in individuals and the ways in which they acted, and saw themselves, as homeowners, consumers or sexual beings. In a study of Madrid during the Spanish Civil War, Michael Seidman has even made explicit use of such an angle to explore those behaviours that did not fit neatly into any collective identity and were at odds with calls for sacrifice and solidarity. ${ }^{11}$ A mere pejorative view is clearly less common than among urban theorists. Moreover, several recent publications marshal individuality and individualism for synthetic purposes. They argue that such a focus can shed new light on particular periods of, respectively, German and British history. In so doing, they implicitly or explicitly draw connections to cities. ${ }^{12}$ While the importance

M. Clapson, 'The new suburban history, New Urbanism and the spaces in-between', Urban History, 43 (2016), 336-41.

${ }^{8}$ R. Brubaker and F. Cooper, 'Beyond “identity"', Theory and Society, 29 (2000), 1-47, at 17-19.

${ }^{9} \mathrm{~S}$. Wagg and P. Bramham, 'Barcelona of the north? Reflections on postmodern Leeds', in Wagg and Bramham (eds.), Sports, Leisure and Culture in the Postmodern City (Farnham, 2009), 189-210, at 189-93, quotation on 191.

${ }^{10}$ B. Holtzman, “'I am not co-op!” The struggle over middle-class housing in 1970s New York', Journal of Urban History, 43 (2017), 864-85, at 878. See also, on late twentieth-century New York City, the insightful anthropological study by A. Kusserow, 'De-homogenizing American individualism: socializing hard and soft individualism in Manhattan and Queens', Ethos, 27 (1999), 210-34.

${ }^{11}$ M. Seidman, 'Individualisms in Madrid during the Spanish Civil War', Journal of Modern History, 68 (1996), 63-83. A social historian, Seidman offers a typology of subversive, acquisitive and entrepreneurial individualisms.

${ }^{12}$ M. Föllmer, Individuality and Modernity in Berlin: Self and Society from Weimar to the Wall (Cambridge, 2013); M. Föllmer, 'Wie kollektivistisch war der Nationalsozialismus? Zur Geschichte der Individualität zwischen Weimarer Republik und Nachkriegszeit', Beiträge zur Geschichte des 
of our theme is thus increasingly recognized, what is still lacking are attempts to draw different case-studies together under this conceptual angle. This is what the present essay set outs to do, building on a broad reading of relevant urban historians in conjunction with some continental sociologists of individuality.

Scholars such as Niklas Luhmann and Uwe Schimank in Germany and Bernard Lahire in France have decisively moved beyond two classic teleological narratives: that the individual is on an irresistible rise undermining social cohesion or, conversely, is undergoing an inexorable decline in an age of rationalization and mass culture. ${ }^{13}$ Instead, they emphasize that individuality and collectivity can assume various forms; that they are mutually dependent, and their relationship does not constitute a zero-sum game; and that notions of individuality are appropriated in different contexts and engender complex social effects. In so doing, they build on Georg Simmel's insights while offering a broader picture. The individuals they foreground are similarly free from traditional constraints but less subjected to rationality and impersonality. They explore cultural options, direct demands to the authorities and engage with other subjects as well as objects. Also in contrast to Simmel, these sociologists of individuality mention the city in passing, as a setting of modern life, without discussing it in any detail. Hence, they have not had a discernible impact on urban sociology or urban studies. Yet their work is eminently relevant to the study of cities, provided that the connection is drawn and explored.

The remainder of this essay is devoted to such an exploration. The contention is that individuality constitutes a key dimension of modern cities and should therefore be studied historically. Individuality and collectivity are umbrella terms for a variety of phenomena, while also marking scholarly perspectives that yield distinct insights when applied to urban society. ${ }^{14}$ This is not just important in its own right. It might also stimulate the discussion of geographically and chronologically overarching trends in a field that traditionally prefers the local case-study and is mostly reluctant to engage with sociological approaches. The focus here will be on three key dimensions of modern cities, all of which begin to look differently when viewed from the vantage point of individuality: first, sites of social and cultural life; secondly, politics

Nationalsozialismus, 29 (2013), 30-52; Emily Robinson et al., 'Telling stories about post-war Britain: popular individualism and the "crisis" of the 1970s', Twentieth Century British History, 28 (2017), 268-304. James Vernon, Distant Strangers: How Britain Became Modern (Berkeley, 2014), ch. 2, analyses the emergence of urban Britain from the vantage point of Simmel's sociology of the stranger but is less interested than Föllmer or Robinson et al. in the semantics of individuality.

${ }^{13}$ On these narratives, see M. Schroer, Das Individuum der Gesellschaft (Frankfurt, 2000), chs. 1-2. Schroer attributes the first narrative of the individual's rise jeopardizing social cohesion to Émile Durkheim and Talcott Parsons. As representatives of the second narrative of individual's tragic decline through rationalization or mass culture, he cites Max Weber and Max Horkheimer/Theodor W. Adorno. One might add that the often-cited works of Richard Sennett and Zygmunt Bauman combine both narratives by highlighting the rise of privacy at the expense of public life as well as the 'corrosion' of true individuality through flexibility and consumerism. See R. Sennett, The Fall of Public Man (rev. edn, London, 2000); R. Sennett, The Corrosion of Character: The Personal Consequences of the Modern Capitalism (New York, 2000); Z. Bauman, Liquid Modernity (Cambridge, 2000), ch. 2.

${ }^{14}$ Interesting recent explorations of collectivity include 'Special section: in search of the social', Journal of Urban History, 42 (2016), 987-1046; A. Sammartino, 'Mass housing, late modernism, and the forging of community in New York City and East Berlin, 1965-1989', American Historical Review, 121 (2016), $492-521$. 
and government; thirdly, non-humans such as material objects, animals and natural elements.

\section{Cultural preferences and fluid spaces}

At sites of social and cultural life, communities, classes and crowds encounter each other and are thus sustained or constituted in the first place. By definition, such sites are collective. Many scholars view them principally as public spaces and then ask to what extent this ideal was reached, i.e. how accessible they were to different social classes, sexes and ethnicities. ${ }^{15}$ However, sites of social and cultural life can also be viewed as settings in which modern individuality was presented, stimulated or indeed created. Again, two existing studies demonstrate the difference that such a perspective can make.

Vanessa Schwartz, in her prominent book Spectacular Realities, interprets the morgue, the wax museum and the panorama in fin-de-siècle Paris as sites where people gathered and a new type of crowd formed. Schwartz's aim is to offer an alternative to the time-honoured critique of mass culture as alienating and isolating. Instead, she focuses on how 'a common culture and a sense of shared experience' were created, 'a new collectivity was constituted' and 'individual city-dwellers' were transformed "into "Parisians"'. ${ }^{16}$ Her interest in crowd formation under modern conditions, through a conjunction of visual spectacle and popular spectatorship, has proven highly fruitful. Yet one might argue that, in distancing herself from a view of 'detached individuals lost in the crowd' and stressing that 'the urban mob happily assembled as a new collective in front of the spectacle of the real, ${ }^{17}$ Schwartz gives short shrift to individual city dwellers as such, their different backgrounds, preferences and experiences.

Paul Metzner's little-known study Crescendo of the Virtuoso, by contrast, is more aware that sites of social and cultural life have an individualist dimension. ${ }^{18}$ Focusing on the century from 1750 to 1850 , Metzner shows how Paris became a city of 'spectacle, skill and self-promotion'. In addition to musical performers such as Niccolò Paganini or Franz Liszt, his examples are chess players, restaurant chefs, police detectives and automaton builders. Virtuosos were beneficiaries of a cultural shift toward deeming individuals of little social standing to be capable of outstanding achievements and entitled to publicize them. They honed their technical skills to the point of turning them into an occupation and exhibited them in new public spaces: concert halls, cafés, restaurants, court rooms or the Palais Royal (where the aforementioned automata were paraded). Much like revolutionary orators, virtuosos achieved media prominence and drew simultaneously on

\footnotetext{
${ }^{15} \mathrm{~A}$ recent example of this approach is J.J.S. Korhonen, 'Urban social space and the development of public dance hall culture in Vienna, 1780-1814', Urban History, 40 (2013), 606-24. A conceptually more innovative article is J. Ryan, "Unveiling" the tramway: the intimate public sphere in late Ottoman and Republican Istanbul', Journal of Urban History, 42 (2016), 1-24.

${ }^{16}$ V. Schwartz, Spectacular Realities: Early Mass Culture in Fin-de-Siècle Paris (Berkeley, 1999), 6, 16, 26.

${ }^{17}$ Ibid., 44.

${ }^{18}$ P. Metzner, Crescendo of the Virtuoso: Spectacle, Skill, and Self-Promotion in Paris during the Age of Revolution (Berkeley, 1998). See also, on a related theme and with ample evidence from Paris, A. Lilti, The Invention of Celebrity 1750-1850, trans. L. Jeffrees (Cambridge, 2017).
} 
enlightened and romantic notions of individuality, on rational self-improvement and emotional authenticity alike. ${ }^{19}$ There is no evidence that Metzner read Simmel or indeed any other sociologist of individuality, but he arrived at similar insights and applied them to the study of one city in a particular period.

A compelling sociological interpretation of how individuals use cultural offerings is proposed by Bernard Lahire. Lahire aims to provide an alternative to Pierre Bourdieu's La distinction, which endeavoured to show how class differences translate into aesthetic choices. ${ }^{20}$ As the title of his book, La culture des individus, suggests, he focuses on how individuals appropriate culture according to personal preferences. In so doing, they develop profils dissonants, for which philosophers Ludwig Wittgenstein and Jean-Paul Sartre, who both loved crime novels, serve as cases in point. ${ }^{21}$ The frequent surprise at such dissonance stems from an overly consonant or coherent model of individual behaviour, which should instead be interpreted as the result of socialisations multiples over time, ranging from families to educational institutions, from circles of friends to marriages. Lahire's point is thus not to posit individuals as autonomous beings but to contextualize them in more subtle fashion than through the prism of social inequality alone. ${ }^{22}$ Individuals make cultural choices but under conditions not of their own making. Furthermore, interviewing them reveals variations intra-individuelles, which can be enjoyed and justified but which can also lead to struggles between a legitimate and an illegitimate self. Although Lahire's focus is on the demand for culture, he also has interesting things to say about the supply side. Libraries, museums and theatres on the one hand and radio and television channels on the other work according to starkly different principles and hierarchies, thus providing the cultural offerings on which individuals draw in their mostly dissonant ways.

Lahire argues that Bourdieu's class-based interpretation of cultural consumption is less apt for the 1960s and 1970s, when he conducted his research, but overlooked the fact that dissonant profiles already existed, than for the more rigidly structured, pre-mass-media society of the late nineteenth century. ${ }^{23}$ At other points, he seems to suggest that even in 'periods of greater separation of genres, arts and publics' there has always been the homo pluralis hiding in the shadow. ${ }^{24}$ This is an interesting issue for urban historians to explore. It might be productive to assume a tension between consonance and dissonance and then ask how this tension changed over time. Many studies have shown that in nineteenth-century cities, social and cultural life was divided between the middle and working classes. Museums, theatres and

\footnotetext{
${ }^{19}$ See also G. Simmel, 'Die beiden Formen des Individualismus', in Simmel, Aufsätze und Abhandlungen 1901-1908, 57-63.

${ }^{20}$ P. Bourdieu, Distinction: A Social Critique of the Judgment of Taste, trans. R. Nice (London, 2010; orig. edn 1979).

${ }^{21} \mathrm{~B}$. Lahire, La culture des individus: dissonances culturelles et distinction de soi (Paris, 2004). For summaries in English, see 'The individual and the mixing of genres: cultural dissonance and self-distinction', Poetics, 36 (2008), 166-88; 'Cultural dissonances: the social in the singular', in L. Hanquinet and M. Savage (eds.), Routledge Handbook of the Sociology of Art and Culture (London, 2016), 346-57.

${ }^{22}$ This theoretical approach is more concisely developed in B. Lahire, Dans les plis singuliers $d u$ social: individus, institutions, socialisations (Paris, 2013).

${ }^{23}$ Lahire, La culture des individus, 172, 258.

${ }^{24}$ Lahire, 'The individual and the mixing of genres', 182.
} 
concert halls were decidedly bourgeois in character. Pubs and music halls had a proletarian outlook, and socialists increasingly built an 'alternative culture' of choirs, reading societies and sports clubs. ${ }^{25}$ Notwithstanding the contemporary discourse on homogenization through a new mass culture, early cinema was socially differentiated, too. Middle-class consumers frequented large, centrally located theatres, where they watched high-brow films in silence, whereas the spectators in working-class cinemas commented loudly on the more entertaining flicks shown there. $^{26}$

This said, there is significant evidence of individuals crossing such boundaries and thus developing dissonant cultural profiles as conceptualized by Lahire. Paul Metzner's study of virtuosos shows that in the early nineteenth century, when urban space was otherwise increasingly divided between classes, a diverse public was strolling around in search of entertainment. The early twentieth century provides further evidence of individual boundary-crossing, for instance in two German diaries. Victor Klemperer, professor of Romance languages and literatures and known chiefly as a chronicler of the Third Reich, loved film, and not just the highbrow variety. At the same time, he occasionally felt ashamed of his own tastes, exemplifying the aforementioned struggle between a legitimate and an illegitimate self. When he bumped into an acquaintance in a cinema in Dresden in 1921, there was a moment of awkwardness, before both found common ground in owning up to their guilty pleasure and sharing their annoyance with the hypocrisy of the educated middle class. ${ }^{27}$ As Peter Fritzsche has demonstrated in an insightful book, the clerical employee Franz Göll possessed multiple selves. His extensive diary echoed contemporary fears of degeneration and conveys a downtrodden impression of his life. According to his household account books, however, Göll simultaneously acted as a confident consumer who made ample use of Weimar Berlin's cinemas, theatres and popular lecture hall Urania. ${ }^{28}$

Some scholars interpret similar boundary-crossings as collective acts by social classes. ${ }^{29}$ By contrast, urban historians have recently become more open to acknowledging individual dissonance, albeit somewhat implicitly. The study of entertainment districts is a case in point. Judith Walkowitz's and Frank Mort's books on Soho show how Londoners and tourists alike went there to transgress the cultural confines of their own class. In areas offering fashionable attire and exotic food as well as dance halls and stages for erotic performances one could broaden, if not deepen, one's individuality. Conversely, Soho was a breeding ground for new entrepreneurs from immigrant backgrounds who succeeded in adapting to shifting

\footnotetext{
${ }^{25}$ V. Lidtke, The Alternative Culture: Socialist Labor in Imperial Germany (New York, 1985).

${ }^{26}$ K.-C. Führer, 'Auf dem Weg zur "Massenkultur"? Kino und Rundfunk in der Weimarer Republik', Historische Zeitschrift, 262 (1996), 739-81, at 755-66.

${ }^{27} \mathrm{~V}$. Klemperer, Leben sammeln, nicht fragen wozu und warum: Tagebücher 1918-1924 (Berlin, 1996), 442 (8 May 1921).

${ }^{28}$ P. Fritzsche, The Turbulent World of Franz Göll: An Ordinary Berliner Writes the Twentieth Century (Cambridge, MA, 2013), 34-59.

${ }^{29}$ See, for instance, P. Bailey, 'Conspiracies of meaning: music-hall and the knowingness of popular culture', Past and Present, 144 (1994), 138-70, 166-7, who sees the 'growing middle-class presence' in the late Victorian music hall as 'evidence of a dominant class learning how to enjoy being in conspiracy against itself.
} 
consumer preferences. Italian restaurant chefs or the Jewish proprietors of costumier shops, theatres and jazz clubs demonstrated self-reliance and rose to individual affluence while maintaining their ethnic identity, a pattern that could entail starkly different political stances. ${ }^{30}$

One can take this further and view large parts of European cities as sites of individual boundary-crossing. Classically, this has led to the objection that such flânerie was reserved for middle-class, white, heterosexual men. However, while the privileged position of that group is not in doubt, it is striking just how much others strove to expand their personal access to urban space. The pursuit of Soho's attractions hinged on the lowly paid and strictly regimented work of female staff, but young female Londoners also came there to engage in dancing and flirting. And as early as the Victorian period, middle-class women campaigned for unchaperoned and unharassed movement across London, whereas others carved out a space in social reform or investigative journalism. ${ }^{31}$ In the twentieth century, queer and non-white men were contained by draconian and discriminatory policing while also challenging and undermining it. They used the complexity of the big city's public and private spaces to escape rigid classifications and seek new experiences. ${ }^{32}$

Urban sites of social and cultural life can usefully be understood through the lens of classes and crowds, but this section has argued that it is at least equally profitable to interpret them as testing grounds for individuals' cultural dissonance. The extent to which Bernard Lahire's concept applies to a particular time and place is, of course, open to empirical research and scholarly debate. But it does provide a perspective that is still fresh yet already being explored implicitly. In modern times, a wide and growing range of city dwellers have claimed the opportunity to explore urban space and broaden their own individuality. Demands for better street lighting show how this claim translated into new expectations of municipal authorities. ${ }^{33} \mathrm{It}$ is to the relationship between the sociology of individuality and the history of urban governance that we now turn.

\section{Political expectations and subjective liberations}

Like the sites of social and cultural life, urban politics and government are classically viewed through the prism of collectivity. The assumption is that social and ideological differences have been represented through political parties and mass

\footnotetext{
${ }^{30}$ J.R. Walkowitz, Nights Out: Life in Cosmopolitan London (New Haven, 2012); F. Mort, Capital Affairs: London and the Making of the Permissive Society (New Haven, 2010). On another prominent entertainment district, see J. Sneeringer, “'Assembly line of joys”: touring Hamburg's red light district, 1949-1966', Central European History, 42 (2009), 65-96.

${ }^{31}$ E.D. Rappaport, Shopping for Pleasure: Women in the Making of London's West End (Princeton, 2001); S. Koven, Slumming: Sexual and Social Politics in Victorian London (Princeton, 2004), chs. 3 and 4.

${ }^{32}$ On queers see, for instance, M. Houlbrook, Queer London: Perils and Pleasures in the Sexual Metropolis, 1918-1957 (Chicago, 2005); M. Cook and J.V. Evans (eds.), Queer Cities, Queer Cultures: Europe since 1945 (London, 2013). On non-white migrants, compare C. Rosenberg, Policing Paris: The Origins of Modern Immigration Control between the Wars (Ithaca, 2006), with M. Goebel, Anti-Imperial Metropolis: Interwar Paris and the Seeds of Third-World Nationalism (Cambridge, 2015), chs. 1-3.

${ }^{33} \mathrm{~N}$. Kenny, 'City glow: streetlights, emotions and nocturnal life, 1880s-1910s', Journal of Urban History, 43 (2017), 91-114, at 101-5.
} 
media. For instance, a study of German mayors in the twentieth century states that this elite, across drastic systemic changes and notwithstanding their parallel duties towards the state, 'had to respond to collective aspirations and interests'. ${ }^{34}$ A chapter on their French counterparts concurs with this view but takes it one step further by stressing that mayors played an important role in creating collectivity in the first place. The authors distinguish between 'three types of activity: providing services to the population; integrating political parties and groups; aggregating the urban population'. 35 The focus on collectivity in the study of urban politics and governance remains important, but this section argues that it should be complemented by greater attention to individuality. ${ }^{36}$

Such a shift in perspective could account for those behaviours and desires that did not fit neatly into collective categories. Much evidence suggests that these were important enough to concern the class-fixated parties of the left, whose mission it was to unite their voters' personal quest for a better life through powerful ideologies and organizations. During the German Revolution of 1918/19, Social Democrats expressed their dismay regarding stubborn Berliners who played cards in factories or articulated their idiosyncratic views during tram rides. Their rationalist emphasis on self-control steering individuals through a difficult transitionary period ran counter to a widespread urge to shake off the constraints of military or quasimilitary discipline. ${ }^{37}$ German communists faced similar problems during the revolution in the aftermath of the First World War as well as later during the depression of the early 1930s. Some proletarians ignored collective discipline in favour of 'individual terror', acting on their own against Nazi stormtroopers, while others sought a bit of entertainment, preferring bourgeois tabloids over the dryly ideological party newspaper. ${ }^{38}$ Meanwhile, mass unemployment demonstrated the fragility of 'the' working class. Under pressure to cater for a diverse constituency, Berlin's communists reluctantly began to adapt their political offering. They began to publish their own tabloids, which simultaneously spread a message of revolutionary solidarity and engaged with individual trajectories and desires. 39

In inter-war France, where communists had begun to enter municipal government, such pragmatism was even more in evidence. Proletarians in Paris's banlieue rouge were prepared to join demonstrations and express their sympathies with the Soviet Union, but many were also owners of self-built houses who demanded gaslight, road and sewage provision. The mayor of Bobigny to the north of the capital,

\footnotetext{
${ }^{34} \mathrm{~A}$. McElligott, 'Servants of the state, agents of the party, representatives of the people: the German mayoralty in the twentieth century', in J. Garrard (ed.), Heads of the Local State: Mayors, Provosts and Burgomasters since 1800 (Aldershot, 2007), 131-56, at 131.

${ }^{35}$ O. Borraz and E. Négrier, 'The end of French mayors?', in Garrard (ed.), Heads of the Local State, 79-94, at 80.

${ }^{36}$ See also M. Föllmer, 'Urban individuality and urban governance in twentieth-century Europe', forthcoming in S. Gunn and T. Hulme (eds.), Powers of the City: New Approaches to Governance and Rule in Urban Europe since 1500 (London, 2020).

${ }^{37}$ M. Föllmer, 'The unscripted revolution: male subjectivities in Germany, 1918/19', Past and Present, 240 (2018), 161-92, at 166-7, 180-2.

${ }^{38}$ E. Rosenhaft, Beating the Fascists? The German Communists and Political Violence 1929-1933 (Cambridge, 1981), chs. 4 and 5; B. Fulda, Press and Politics in the Weimar Republic (Oxford, 2003), 33-4.

${ }^{39}$ Föllmer, Individuality and Modernity, 87-91.
} 
for instance, dutifully complied with this pressure and spent much of his time lobbying for infrastructural investment in the largely makeshift suburb. ${ }^{40}$ These are only a few examples of a broader tension in twentieth-century urban politics, namely between trying to appeal to people with personal desires and individualist preferences and keeping them under control in the interest of a common objective. This was obviously easier where a left party was able to dominate a particular city, as was the case for communists in Bobigny and Bologna or social democrats in Vienna, who cultivated their own version of a patronage system. ${ }^{41}$ But in many other European cities, even after workers acquired the municipal vote, it was necessary to form broader coalitions that were dependent on a measure of middle-class support and hence particularly vulnerable to the charge of neglecting individuals in favour of 'collectivism'. ${ }^{42}$

It is worth pausing to ask how these individualist desires and expectations might be conceptualized. The broad notion comprises different impulses, among which is a desire for subjective liberation in times of rupture. This was frequent during the German Revolution of 1918/19, which ended years of military or quasi-military discipline during World War I. To play cards at the factory in defiance of managers or foremen, to voice one's opinion without fear of repression, to ignore the constant appeals to patriotic morality were key aspects of rapid cultural change. They were also, as it turned out, a challenge to both the social democratic and the communist political projects. Another instance of such a quest for subjective liberation in times of rupture includes the unrest that culminated in 1968 but was prepared for by artistic happenings in Amsterdam, Munich and Paris and followed by the activities of squatters and other vanguards of 'alternative' ways of life. Engaging in joyful debates and throwing stones at the police as well as picnicking in the street or sunbathing on roof terraces reflected a quest to experience moments of freedom and authenticity that were both embodied and emotional. ${ }^{43}$ It was precisely this momentous, intensely personal character of radical activism that made it so difficult for the authorities to crush or integrate - and, at the same time, so difficult for the New Left to convert into lasting collective movements. ${ }^{44}$

\footnotetext{
${ }^{40}$ T. Stovall, The Rise of the Paris Red Belt (Berkeley, 1990), ch. 5.

${ }^{41} \mathrm{H}$. Bodenschatz, 'Bologna and the (re-)discovery of urban values', in M. Baumeister, B. Bonomo and D. Schott (eds.), Cities Contested: Urban Politics, Heritage and Social Movements in Italy and West Germany in the 1970s (Frankfurt, 2017), 211-28; M.P. Berg, "Reinventing "Red Vienna" after 1945: habitus, patronage and the foundations of municipal social democratic dominance', Journal of Modern History, 86 (2014), 603-32.

${ }^{42}$ Such a charge was, for instance, levelled in 1902 by The Times against municipal interventionism in Glasgow; see I. Maver, 'The role and influence of Glasgow's municipal managers, 1890s-1930s', in R.J. Morris and R.H. Trainor (eds.), Urban Governance: Britain and Beyond since 1750 (Aldershot, 2000), 69-85, at 75 .

${ }^{43}$ L. Batigny, 1968: de grands soirs en petits matins (Paris, 2018), chs. 8-11; J. Häberlen, The Emotional Politics of the Alternative Left: West Germany, 1968-1984 (Cambridge, 2018).

${ }^{44}$ The available theorizations of such activism tend to reflect normative stances. For a sympathetic and stimulating take on subjectivation politique in revolutionary situations, see F. Tarragoni, Sociologies de l'individu (Paris, 2018), 106, and L'énigme révolutionnaire (Paris, 2015), esp. chs. 4 and 7. By contrast, Uwe Schimank clearly prefers a more thoughtful and stable reflexiver Subjektivismus; see 'Jenseits Gottes und des Nichts: Funktionale Differenzierung und reflexiver Subjektivismus', in U. Schimank, Das zwiespältige Individuum: Zum Person-Gesellschaft-Arrangement der Moderne (Wiesbaden, 2002), 65-86.
} 
Aside from, and in parallel to, subjective liberation, political individuality entailed the development of more stable expectations, especially regarding homeownership and infrastructural provision. German sociologists Niklas Luhmann and Uwe Schimank have theorized these as Anspruchsindividualität. Anspruch translates as 'claim' or 'entitlement'. According to Luhmann and Schimank, persons direct these claims or entitlements to different subsystems of society, for instance the political, health or welfare systems. They demand to be included to balance out their ambivalent freedom in modern times, to be addressed as voters, treated as patients or supported as clients. ${ }^{45}$ But even these more stable expectations are highly diverse and also shifting. They have historically been, and still are, understood both as the right to be treated equally to everyone else and the entitlement to have one's unique situation recognized and catered for. ${ }^{46}$ This dual claim has resulted in a tension between standardization and individualization. Hence, Luhmann's apt formulation that 'social inclusion of individuals needs to be more and more arranged through organization', while individuals have, in an apparent paradox, become 'capable of retreat and unreliable'. 47

These considerations would suggest that the relationship between governments and subjects should be reconceptualized. The predominant concept in this regard is currently gouvernementalité, as developed by Michel Foucault and many subsequent authors. ${ }^{48}$ 'Governmentality' differs from older notions of governance. It foregrounds that an array of ideas and practices did not so much subject individuals directly but brought them to participate in their own regulation - through governing themselves, as it were. Such controlled activation of subjects allowed municipal authorities to go beyond the creation of 'collective agencies' and the 'use of bureaucratic forms in which individual actions were bound by rules and regulations'. ${ }^{49}$ Patrick Joyce's The Rule of Freedom shows how this 'active and inventive deployment of freedom as a way of governing or ruling people' worked in the context of Victorian cities. According to Joyce, urban liberalism based itself on a range of maps and statistics in the interest of knowing the city and its residents. It pursued an ideal of unfettered circulation, which was implemented through streets and parks, sewers and pipes. This slowly reshaped city dwellers' behaviour, leading to

\footnotetext{
${ }^{45} \mathrm{~N}$. Luhmann, 'Die gesellschaftliche Differenzierung und das Individuum', in N. Luhmann, Soziologische Aufklärung 6: Die Soziologie und der Mensch, 2nd edn (Wiesbaden, 2005), 121-36, at 12833; U. Schimank, 'Anspruchsindividualismus', in Schimank, Das zwiespältige Individuum, 281-94.

${ }^{46}$ See, again, the distinction in Simmel, 'Die beiden Formen des Individualismus'; also Pierre Rosanvallon's apt remark that equality has come to mean 'the possibility of making [public institutions] take the particularity of one's situation into account, of seeing it appreciated in all its dimensions': $\mathrm{La}$ légimité démocratique: impartialité, réflexivité, proximité (Paris, 2008), 157.

${ }^{47} \mathrm{~N}$. Luhmann, 'Individuum, Individualität, Individualismus', in N. Luhmann, Gesellschaftsstruktur und Semantik: Studien zur Wissenssoziologie der modernen Gesellschaft, vol. III (Frankfurt, 1993), 149-258, at 253, 255.

${ }^{48}$ See G. Burchell, C. Gordon and P. Miller (eds.), The Foucault Effect: Studies in Governmentality. With Two Lectures by and an Interview with Michel Foucault (Chicago, 1991); M. Foucault, Security, Territory, Population: Lectures at the Collège de France, 1978-1979 (Basingstoke, 2009); M. Foucault, The Birth of Biopolitics: Lectures at the College de France, 1978-1979 (Basingstoke, 2010).

${ }^{49}$ These are noted as key tenets of nineteenth-century urban governance in R.J. Morris, 'Governance: two centuries of urban growth', in Morris and Trainor (eds.), Urban Governance, 1-14, at 6.
} 
the creation of a new kind of individuated subjectivity with moral as well as political dimensions. $^{50}$

Joyce does acknowledge that there was also resistance against the liberal effort of governance, especially in the 'unstable and undependable' arena of the street, where alternative versions of urbanity were narrated, sung or enacted. ${ }^{51}$ Yet, subjective liberation and Anspruchsindividualität open up a different and, certainly for the twentieth century, no less plausible perspective than gouvernementalité and the resistance against it. With the help of these notions, historians might explore how urban politicians and institutions have struggled to satisfy the myriad individualist expectations with which they were confronted. The notions also capture the fact that these personal demands were themselves diverse, ranging from freedom from to support by bureaucracy, from momentous desires to stable expectations. And, in this context, mayors had to appear personally approachable and identifiable in order to reflect and represent a society of individuals while also giving it unity and direction. On a smaller scale, cities were thus sites of a broader history of leadership in modern times. ${ }^{52}$

\section{Individuality in the 'more-than-human city'}

In recent years, the 'more-than-human city' has come to be an object of conceptual attention. ${ }^{53}$ Material objects and built structures, animals such as rats, foxes and dogs, and natural elements such as fire and water have all been ascribed a structuring role in urban society. Actor-network theory as developed by French sociologist Bruno Latour underpins this expanded concept of agency. ${ }^{54}$ It has been enthusiastically taken up by some theoretically inclined urban historians. ${ }^{55}$ Bert de Munck has suggested drawing on actor-network theory in order 'to re-analyse how urbanization is related to such broader societal transformations as the advent of capitalism, individualism and liberalism'. ${ }^{56}$ What might the opposite perspective look like, i.e. approaching objects, animals or natural elements from the vantage point of the sociology of individuality? Here, it is worth returning to Georg Simmel. In his Philosophie des Geldes, first published in 1900, Simmel argued that the impersonal medium of money had opened up new spaces for independence from other subjects and from particular objects, all of which were interchangeable. But precisely by levelling variety, money enabled 'the most adequate realization and effectiveness of every

\footnotetext{
${ }^{50} \mathrm{P}$. Joyce, The Rule of Freedom: Liberalism and the Modern City (London, 2003), 1.

${ }^{51}$ Ibid., 16.

${ }^{52}$ See M. Föllmer, 'Leadership in modern times: reflections on Yves Cohen's Le siècle des chefs', History, Culture and Modernity, 2 (2014), 65-81; Y. Cohen, Le siècle des chefs: une histoire transnationale du commandement et de l'autorité (1891-1940) (Paris, 2013).

${ }^{53}$ A. Franklin, 'The more-than-human city', Sociological Review, 65 (2017), 202-17.

${ }^{54}$ The theoretical foundations are laid out in B. Latour, Reassembling the Social: An Introduction to Actor-Network-Theory (Oxford, 2005).

${ }^{55}$ I. Farías and T. Bender (eds.), Urban Assemblages: How Actor-Network Theory Changes Urban Studies (London, 2010); S. Gunn, 'Urban agency: debating the aims and limits of urban history', Urban History, 44 (2017), 110 .

${ }^{56} \mathrm{~B}$. de Munck, 'Re-assembling actor-network theory and urban history', Urban History, 44 (2017), 11122 , at 115 .
} 
individual complication'. This entailed that individuals could choose to define their identity through their possessions, which thus became 'an extension of the Ego'. ${ }^{57}$

In a complementary sociological analysis to Simmel's, Uwe Schimank has coined the term ästhetische Sinnlichkeit (aesthetic sensuality). This means that objects are converted into quasi-subjects, enabling the joy of driving a car, cycling along a river on a prized bike or running beneath trees wearing sneakers of the latest design. ${ }^{58}$ Such a perspective would allow for interesting historical explorations into, for instance, automobility as a way of extending one's individuality and pursuing it in cities and conurbations as well as, on weekends, in 'nature'. No doubt, urban drivers have often been joyful, as Schimank stresses, but as often they have been angry at the presence of other individuals in cars or the limitations imposed by traffic signs and roadworks. In that sense, automobility was closely linked to a spirit of progressive optimism but eventually came to reflect its limitations. ${ }^{59}$ Further interesting topics would be the history of collectors of valuable stamps or coins, antique books and vintage furniture with their idiosyncratic browsing of specialized shops and markets, also that of photographers and their peculiar ways of exploring the city with their cameras. ${ }^{60}$

The strikingly ingenious ways in which subjects develop and expand their individuality in conjunction with things should, however, not obscure the other side of that relationship. Undoubtedly, individuality has been, and still is, constrained by material expressions of social inequality. Instead of experiencing ästhetische Sinnlichkeit, welfare clients are confronted with a spatial environment designed to control and steer them. As Wiebke Wiede has argued for the 1970s and 1980s, waiting rooms with plastic chairs, numbers to draw and forms to complete, pinboards with offers of work in British job centres, microfilm readers and then computers in West German labour offices were actants of Subjektivierung, to which the unemployed could react but which they were unable to shape. ${ }^{61}$ The built environments of American ghettos or poor French suburbs provide a further case in point. Here, social and racial segregation manifests itself in motorways cutting through residential neighbourhoods or in concrete high-rises that have long acquired an oppressive character even though they were initially informed by a

\footnotetext{
${ }^{57}$ G. Simmel, The Philosophy of Money, ed. D. Frisby, trans. D. Frisby and T. Bottomore, 2nd edn (London, 1990), 319, 322.

${ }^{58}$ U. Schimank, 'Dialogische Sozialität und ästhetische Sinnlichkeit: Die zwei Dimensionen einer identitätssichernden Lebenswelt', in Schimank, Das zwiespältige Individuum, 119-32.

${ }^{59}$ Attention to individuality in conjunction with car-driving could fruitfully complement the emerging historiography of urban automobility. See, e.g., M. Flonneau, Paris et l'automobile: un siècle de passions (Paris, 2005); several chapters in L.H. Siegelbaum (ed.), The Socialist Car: Automobility in the Eastern Bloc (Ithaca, 2011); S. Gunn, 'Ring road: Birmingham and the collapse of the motor city ideal in 1970s Britain', Historical Journal, 61 (2018), 227-48.

${ }^{60}$ See D. Miller (ed.), Anthropology and the Individual: A Material Culture Perspective (Oxford, 2009), which has interesting overlaps with the sociological work foregrounded in the present article. On the individualism of Berlin's photographers around 1900, see K. Zelljadt, 'Capturing a city's past', Journal of Visual Culture, 9 (2010), 425-38, at 431-3.

${ }^{61}$ W. Wiede, 'Von Zetteln und Apparaten: Subjektivierung in bundesdeutschen und britischen Arbeitsämtern der 1970er- und 1980er-Jahre', Zeithistorische Forschungen, 13 (2016), 466-87.
} 
notion of the citizen-consumer. ${ }^{62}$ These environments, too, provide spaces for fostering individuality, for instance in sports or music, but this should not diminish the very real constraints they impose.

Alongside material objects and structures, animals have increasingly been discovered as agents in their own right. To capture how animals have been related to urban individuality, one can draw on dialogische Sozialität, Schimank's twin notion to ästhetische Sinnlichkeit. It means that the status of subjects is ascribed to others, so that socializing and dialogue rather than mere instrumentalization become possible. ${ }^{63}$ This fits with the tendency of individuals as they emerged in the nineteenth century to treat animals as subjects who should be exempt from violence, at least in public. Hence, the campaigns against horse-whipping by carriage drivers, slaughtering in city centres or cockfights in residential neighbourhoods. Moreover, the new individuals increasingly desired the company of pets. In a pioneering book on Paris, Kathleen Kete has seen in this the 'fault lines of and a 'continuing statement of protest against bourgeois individualism', or even evidence of its 'demonic and self-destructive' character. ${ }^{64}$ This is, however, a strongly normative and analytically questionable choice, for much of what Kete describes as the 'projection of bourgeois personality onto canine behaviour' could just as well be interpreted as attempts to cultivate and enrich one's individuality through dialogische Sozialität with dogs, by elevating them to the status of fellow individuals. ${ }^{65}$ Similar things might be said about interactions between urban subjects and a range of animals, for instance in Spanish bullfighting with its unpredictable bovine agency, anthromorphizing rhetoric and masculine stardom (after female bullfighters had been increasingly marginalized in the course of the nineteenth century). ${ }^{66}$

In addition to material objects and animals, natural elements are now seen as exerting a specific form of agency. Floods are a prime example of how such agency has affected urban societies but also of how it was intertwined with notions of individuality and collectivity. The Hamburg Flood of 1962 provides a pertinent casestudy. ${ }^{67}$ The local press at one and the same time criticized citizens for lacking a sense of personal responsibility and consequently ignoring the warning sirens and applauded them for revitalizing a long-lost communal spirit in an emergency situation. In parallel, this emergency situation called for a particular kind of individuality, namely that of the political leader. Helmut Schmidt, then the city-state's

\footnotetext{
${ }^{62}$ W.H. Sewell, Jr, 'Refiguring the "social" in social science: an interpretivist manifesto', in W.H. Sewell, Logics of History: Social Theory and Social Transformation (Chicago, 2005), 318-72, at 367-8; K. Cupers, The Social Project: Housing Postwar France (Minneapolis, 2014).

${ }^{63}$ Schimank, 'Dialogische Sozialität'.

${ }^{64} \mathrm{~K}$. Kane, The Beast in the Boudoir: Petkeeping in Nineteenth-Century Paris (Berkeley, 1994), 2, 33, 101.

${ }^{65} \mathrm{Ibid}$., 96 . The equivalence between humans and animals as disciplined subjects is emphasized (in my view overemphasized) in Joyce, Rule of Freedom, 88. C. Wischermann, A. Steinbrecher and P. Howell (eds.), Animal History in the Modern City: Exploring Liminality (London, 2019), is interested in the interrelated nature of animal and human histories' (back cover) but not, as far as I can see, in individuality.

${ }^{66} \mathrm{~A}$. Shubert, Death and Money in the Afternoon: A History of the Spanish Bullfight (Oxford, 2001), chs. 2 and 3.

${ }^{67}$ The following remarks are based on M. Hessler and C. Kehrt (eds.), Die Hamburger Sturmflut von 1962: Risikobewusstsein und Katastrophenschutz aus zeit-, technik- und umweltgeschichtlicher Perspektive (Göttingen, 2014); F. Mauch, Erinnerungsfluten: Das Sturmhochwasser von 1962 im Gedächtnis der Stadt Hamburg (Hamburg, 2015).
} 
senator of the interior, was widely praised for requesting the help of the armed forces, even though his request was unconstitutional. In a rhetoric that recalled the Nazi era, the magazine Der Spiegel applauded Schmidt's initiative and declared him the 'master of the flood': 'The Hanse city of Hamburg was leaderless and incapable of appointing a leader. The Führer answered his own call. ${ }^{68}$ The Hamburg Flood greatly boosted the future chancellor of the Federal Republic's career. But the rhetoric surrounding it, foregrounding as it did forceful leaders and resilient communities, obscured how other people were affected on an individual level. The hardest hit were former refugees in the poor Wilhelmsburg district, whose enforced self-reliance had consisted of living in makeshift homes that proved especially vulnerable to the onslaught of the water. It was only later, from the 1970s, that a commemorative space began to open up in which such individual stories of experiencing the flood in a disadvantaged and isolated position could resurface.

Urban individuality has been extended through material objects and animals, but has also been limited or challenged by built environments and natural elements. The 'positive' side of this complex relationship can be studied under the lens of ästhetische Sinnlichkeit and dialogische Sozialität as suggested by Uwe Schimank. Its 'negative' side, namely how situations of oppressiveness or emergency affect urban individuality, awaits a satisfying theorization. Together, both could complement the recent conceptual emphasis on the 'more-than-human city'.

\section{Conclusion}

This article has discussed, and attempted to take further, existing explorations of individuality in urban society and related them to other dimensions: sites of social and cultural life; politics and government; and the 'more-than-human city' of animals, objects and natural elements. Such an analysis can benefit from the classic as well as the contemporary sociology of individuality - a literature that may seem somewhat opaque at first (and has mostly not been translated into English) but offers some ultimately straightforward insights as well as considerable common ground between different authors. These sociologists stress that individuality entails many strands and aspects; that it is principally a matter of claims and ambitions, which may or may not be realized depending on resources and contexts; and that it does not stand in contradiction to, but rather in a complementary relationship with, social life, governance and the environment.

Rich though it is in both case-studies and relevant theories, the historical analysis of urban society needs further concepts with the capacity to connect different findings and settings. Individuality fits this bill, and its conceptual variations can be applied to several dimensions at once. The notion of profils dissonants has been coined for cultural consumption but might also be relevant to a person's political views or relation to things and animals; Anspruchsindividualität is most apt for the relationship between citizens and their governments, which can be defined to entail the expectation of being protected from environmental damage; dialogische

\footnotetext{
${ }^{68}$ 'Herr der Flut', Der Spiegel, 7 Mar. 1962. I have argued elsewhere against viewing Nazism as categorically distinct from the history of modern individuality, see Föllmer, Individuality and Modernity, chs. 4 and 6; Föllmer, 'Wie kollektivistisch war der Nationalsozialismus?'.
} 
Sozialität might also be found in leisure activities, and ästhetische Sinnlichkeit in visits to the concert hall or the museum.

Sociologists such as Bernard Lahire, Niklas Luhmann and Uwe Schimank have stressed that individuals relate to others, appropriate objects, make use of cultural offerings and voice political demands. They thus associate individuality with personal isolation to a lesser extent than Georg Simmel. This broader understanding is salutary, but at a time when municipal governments are beginning to address loneliness as a key social problem, l'individu incertain as conceptualized by Alain Ehrenberg should also attract urban historians' attention. ${ }^{69}$ In any case, theorists of the city would be well advised to take individuality seriously rather than dismiss it out of antipathy to neoliberalism. For, to cite Simmel one last time, 'it is not our task either to accuse or to pardon but only to understand'. ${ }^{70}$

\footnotetext{
${ }^{69}$ A. Ehrenberg, L'individu incertain (Paris, 1995). See also J.-C. Kaufmann, L'invention de soi: une théorie de l'identité (Paris, 2004), chs. 8-9.

${ }^{70}$ Simmel, 'The metropolis', 424.
}

Cite this article: Föllmer M (2020). The sociology of individuality and the history of urban society. Urban History 47, 311-326. https://doi.org/10.1017/S0963926819000877 